\title{
ПОСЛАННЯ МИТРОПОЛИТА АНДРЕЯ ШЕПТИЦЬКОГО - НАЦІОНАЛЬНО-ДУХОВНА СПАДЩИНА ДЛЯ НАУКОВЦІВ ТА ЖУРНАЛІСТІВ
}

\author{
Мар'ян Лозинський \\ Львівський національний університет імені Івана Франка \\ вул. Генерала Чупринки, 49, 79044, Львів, Украӥна \\ e-mail: mlozynskyj@,lnu.edu.ua \\ https://orcid.org/0000-0002-5006-3291
}

В 2020 році припадає 120-та річниця з того часу, як Митрополит Андрей Шептицький отримав титул Галицького митрополита з осідком при соборі св.Юра у Львові. Статтю присвячено тематичному розгляду його окремих послань, які станом на сьогодні видані в 3 томах в середовищі науковців і дослідників історії за підтримки ієрархії УГКЦ.

Звернено увагу на актуальність ідей, які випливають із послань Митрополита Андрея, для реалій українського суспільства загалом і науковців та журналістів зокрема.

Ключові слова: писемна спадщина, послання, форма, Митрополит Андрей Шептицький, Церква, суспільство, журналістика.

Писемні послання в Україні сягають глибокої давнини. Вони є документами свого часу і відображають тогочасні суспільно-релігійні аспекти розвитку тодішніх спільнот громад. Окрему категорію становлять листи повчального змісту, авторами яких виступали знатні вельможі з високим рівнем освіченості, а також визначні діячі суспільно-політичного та релігійного життя.

Ця традиція послань передавалася від одних мислителів до інших. До них належав і Митрополит Андрей Шептицький, який протягом 44-х років свого єпископського служіння спочатку на Станіславівщині, потім на Львівщині творив окрему епоху в історії УГКЦ. Наступного, 2020-го року, минає 120 років відтоді, як Митрополит Андрей отримав титул Галицького митрополити з осідком при соборі св.Юра у Львові. Загалом ціла душпастирська діяльність Митрополита Андрея у першій половині XX ст. припадає на період Першої світової війни, її руйнівних наслідків; на територіальні поділи в Східній Свропі, а після 1939 року - на німецько-більшовицьку «м’ясорубку» під час Другої світової війни (в радянській історії названа «Великою Вітчизняною»).

Митрополит Андрей, прийнявши богопосвячений стан у Василіянському Чині, протягом непростого для себе часу на Києво-Галицькому престолі, став етнархом і пастирем українського народу. Він проявляв велику активність у пошуках матеріально-фінансової допомоги для багатостраждального українського народу, особли-

(С) Лозинський М., 2019 
во для сиріт і напівсиріт. За різними джерелами, які подають дослідники, на той час в Галичині нараховували близько 20 тис. дітей сиріт [1, С.239].

Актуальність нашої статті випливає із суспільно-політичної і релігійної ситуації в Україні, яка ставить на порядок денний перед сучасною журналістикою нові вимоги щодо захисту України в умовах гібридної війни, яку веде Російська Федерація.

Метою статті є розгляд послань Митрополита Андрея Шептицького та їх сучасне прочитання в контексті нових викликів для України на різних рівнях - суспільному, економічному, релігійному, тощо. Писемна спадщина Митрополита Андрея спонукатиме, на нашу думку, до нових сучасних форм проповідництва у ЗМІ, до розробки стратегічних планів у царині захисту культури й духовності українського народу.

Результати дослідження. Загальновідомо, що деякі лідери Центрально-Східної Свропи та їхні впливові політики намагаються через нацменшини в Україні послаблювати Українську державу. Особливого значення у цьому питанні набувають їхні ЗМІ, які володіють потужним кадровим і технічним потенціалом.

В часи Митрополита Андрея Шептицького гостро стояло питання захисту прав і свобод нашого народу від сусідів, котрі всіляко намагалися розчленувати і поділити між собою молоду Українську державу. Великий Пастир свого народу Андрей це виразно бачив і намагався всіляко цьому перешкодити. В першу чергу він, як глава УГКЦ, разом із духовенством активно спричинявся до покращення долі цілого українського народу, через наймогутніший вияв нашої боротьби за церковні й національні права.

Як духовна особа Митрополит Андрей добре усвідомлював, що найбільш ефективним та дієвим взаємозв'язком зі своїм народом $€$ пастирські послання. У своїх чисельних посланнях та богословських творах він залишив нам Божу науку, яка веде нас до вічного спасіння. Наприклад, в його першому пастирському посланні читаємо: «Так Вас люблю, що готов я Вам подати не лише Божу науку, але й душу - життя своє! Бо Ви дуже дорогі моєму серцю» [2, С.7].

Історія підготовки послань Митрополита Андрея бере свій відлік відтоді, як вірні учні в 1926 році відзначили 25-річчя його перебування на митрополичому престолі при соборі св. Юра. Тодішній єпископ Луцький Йосиф Боцян підготував літературний огляд пастирських послань, котрі з’явилися з під пера галицького владики і котрі він зумів упорядкувати. Наступним кроком у підготовці пастирських видань слід вважати підготовку до відзначення 35-ліття митрополичого служіння владики Андрея. 3 цією метою духовенство Богословської Академії УГКЦ постановило продовжити видання всіх його творів, котрі були розкидані по цілому світу. В основному це були праці Митрополита Андрея з його періоду служіння в Станиславові (нині Івано-Франківськ), котрі увійшли до одного тому пастирських послань. Вже тоді читач мав можливість зануритися в універсальність початківця і талановитого на письменницький дар молодого Митрополита Андрея, який є мов великою горою, біля якої ми стоїмо і не можемо розглядіти її велич та красу. Всю красу, і це знає кожний, можна побачити тільки тоді, коли ти стоїш із самого вершечка гори. Автор передмови професор Анатоль Базилевич пише: «Такою духовною горою був саме Митрополит Андрей. Щойно з віддалі часу будемо могти його оцінити краще, як це ми могли робити за його життя і щойно тоді, коли перестудіюємо глибину його 
думок побачимо й ті виднокрити, що їх він бачив, а багато з нас їх не зауважували або просимо таки не розуміли» [3, С. 13].

Другим виданням послань митрополита Андрея є твори періоду вересня 1939 р. - червня 1941 р., періоду комуністичної «навали» на Західну Україну. Ці послання вийшли у видавництві отців редемптористів «Логос» [4].

Міжвоєнний, прижиттєвий період Митрополита Андрея був насичений різними перевиданнями його творів. Зокрема, це переклад з грецької мови аскетичних творів св. Отця нашого Василія Великого, послання «Як будувати рідну хату», «Божа мудрість» (1932 р.) та ін.

Тематичний аналіз творів Митрополита А. Шептицького з відкриттям архівів чітко показував, що вся його писемно-творча спадщина вимагала від нас, сучасників, укладення повного зібрання творів, які мали би з'явитися у світ і стати доступними для читача, зацікавленого як релігійними, так і суспільними питаннями. Такий час настав, зокрема, з проголошенням незалежності Української держави в 1991 році - послання митрополита Андрея потрапили до рук дослідників історії УГКЦ. У введенні до першого тому пастирських послань (1899-1914 рр.) єпископ Михаїл Гринчишин писав: «По довгих десятиліттях розшуків і досліджень постуляція справи беатифікації Митрополита Андрея розпочинає повне критичне видання його пасторських послань. Передбачено чотири тома» [1, С. 10-11].

При цьому зазначимо, що прогноз владики Михаїла здійснився і всі чотири томи побачили світ. Це була величезна науково-дослідницька праця невеликої групи ентузіастів, поціновувачів титанічної праці Митрополита А. Шептицького, яка увінчала його релігійно-національні потуги в українській історії першої половини XX ст. До них належала й довголітній працівник Центрального державного історичного архіву у Львові канд. істор. наук п. Оксана, яка однією з перших з початку 90-х років минулого століття почала віднаходити писемні твори великого Митрополита і клопотатися про їх видання.

Велична світова постать папа Іван Павло II, святий Католицької Церкви, під час пастирського візиту в Україну (2001р.) так згадує про митрополита: «Як при цьому не згадати далекоглядну й грунтовну пастирську діяльність Слуги Божого Митрополита Андрея Шептицького, справа беатифікації якого ведеться і сподіваємося одного дня побачити його у славі Святих? Треба зробити належне посилання на його героїчну апостольську діяльність, щоб зрозуміти по-людському живучість Української греко-католицької церкви в темні роки переслідування» [5, С. 290].

Серед героїчної душпастирської діяльності Митрополита Андрея важливе місце займає «апостолят пера», який він започаткував ще наприкінці XIX ст., зокрема у стінах василіанського монастиря св. Онуфрія у Львові. Будучи ігуменом цього монашого осідку, молодий о. Андрей заснував у 1897 році релігійний часопис «Місіонар», який став вельми популярним друкованим виданням в Західній Україні. Його наклад в окремі роки міжвоєнного періоду сягав близько 50-ти тисяч примірників. Також 3 під пера тоді ще молодого єпископа Станіславівської єпархії Андрея, а з 1900 року митрополита Галицького виходять численні монографічні праці, десятки послань, листів, які стали живим словом Митрополита для широких верств народу. Про письменницький талант Андрея Шептицького пересічний глядач зміг довідатися сповна лиш тоді, коли після багаторічного вивчення сотень його творів вдалося опрацювати та видати в 2007-2013 роках пастирські послання у 3 томах (видавництво «Артос»). 
Майже всі послання переважно носили богословське, катехитично-повчальне спрямування, які розкривали перед «люблячим» для Митрополита Андрея народом, по простому та доступно, значення глибокої віри в Бога, любові до Батьківщини, до своїх рідних, тощо. Божа ласка та молитва були постійними й улюбленими темами не тільки Митрополита, але й цілого духовенства Галичини, яке поширювало цю його науку серед народу. Слід зазначити, що він дуже багато писав, виходячи насамперед із об'єктивних причин, передусім із внутрішніх. Виникає об'єктивне запитання: а де Митрополит Андрей набирався та черпав 3 отчого джерела своїх думок? Перш за все знайдено відповідь на це та подібні питання у його заповіті, складеному перед Римським Архиєреєм, який став вже доступним. Ось що він пише: «Від тієї пори, коли 3 послуху Вселенському Архиєреєві прийняв я важкий Єпископський уряд, зрозумів я, що моїм обов'язком є провадити своїх вірних до вічного спасіння через віру католицьку в любові до Бога та до його Церкви - то значить, християнізувати життя, думки і тяги навіть патріотизм (курсив - М. Л.) моїх вірних» [6, С. 14].

Читаючи послання Митрополита Андрея, особисто відчуваю невидиму силу, яка просвічує та навчає, а його думка та висловлювання пронизують до самого серця. Він дуже добре знав і бачив психологічні та життєві проблеми рідного народу в Галичині, де в першій половині XX ст. мало місце велике зубожіння та панувала людська кривда. Український народ разом із своїм духовенством перебував у глибокому вирі воєнного лихоліття та чужоземного поневолення. Митрополит це виразно бачив, відвідуючи парафії архиєпархії та перебуваючи у постійній злуці зі своїми вірними, особливо через багатогодинну сповідь.

За класифікацією твори Митрополита Андрея Шептицького можна поділити на богословські, канонічно-конституційні та пастирські послання. В основі останніх лежать його чисельні листи. Ще за життя митрополита його співробітник у Господньому винограднику єпископ Йосиф Боцян здійснив тематичний аналіз 59-ти послань митрополита, зокрема, виділив такі: послання до духовенства й вірних, послання винятково для вірних.

В останній групі послань знаходимо слова митрополита до вірних: «Ставши єпископом, я поставив собі закон якнайчастіше проповідувати Боже слово. Прошу в Бога ласки, дорогі мої Браття і Сестри у ряді послань представити ціну науку, всі правди віри» [2, С. 623].

Цю велику настанову, яка базується на основних принципах християнської моралі, що мали б служити суспільству того часу для оборони української державності, яка тільки но зароджувалася, Митрополит Андрей виконав. Більш того, він був свідомий своєї місії щодо небезпеки для християнської віри, яка випливала від москвофільської православної агітації в Галичині, а також щодо можливого початку Другої світової війни.

«Червоною ниткою» у посланнях митрополита Андрея до вірних пролягає тема його любові до людини, яка випливає із Божої любові, яка, на його думку зможе вилікувати рани на тілі українського народу, котрі у першій половині XX ст. сильно кровоточили. На жаль, так склалися історичні обставини розвитку української державності в XX ст., що й досі ці рани остаточно не заліковані. Суспільний-політичний вектор розвитку України в період нової російсько-української війни потребує активної життєвої позиції кожного українця-християнина. 
Отже, як випливає із писемної спадщини Митрополита Андрея, для участі в суспільному житті світських людей і духовенство повинна спонукати відповідальність за долю України. Великий Пастир застерігав духовенство перед тим, щоб використовувати проповідальницю як трибуну для поширення політичних поглядів, але водночас вважав, що воно має за обов'язок брати активну участь у суспільних перетвореннях. Таким чином, він доводив своїм учням через активну позицію в питаннях суспільно-політичних, культурних і економічних, що Церква не може мовчати і бути пасивною, коли йдеться про гідність та покликання людини, коли держава потребує оборони від збройних зазіхань сусідів, коли панує серед рідного народу безробіття та має місце масова трудова міграція інтелектуально здібних та фізично здорових українців за кордон. Митрополит Андрей виразно бачив в цих процесах драму розділених сімей, розбитих подружь, покалічених дитячих доль... Чи сьогодні не маємо подібну ситуацію, яку викликала «четверта хвиля» української еміграції, щоб була «народжена» антинародною економічною політикою політичної верхівки країни? Адже свого часу вона спонукала українських громадян перетворитися на чорноробів ситих західних суспільств.

Значну увагу у своїх пастирських посланнях Митрополит Андрей приділяє ролі інтелігенції, яка має бути певним просвітником та проповідником для українського народу. Його думки та роздуми базуються на глибокій обізнаності стану справ в письменницькому середовищі, учителів тогочасних політиків. Його особисті контакти із представниками тієї частини галицького суспільства зумовили актуальні звернення до них з приводу побудови «рідної хати». Практично у всіх своїх посланнях Митрополит Андрей не уникає та не боїться діалогу із середовищем інтелігенції, а, навпаки, наголошує на її високій відповідальності та ставить перед нею більші вимоги морального характеру.

Висновки. Коротко підсумовуючи актуальність писемно-творчої спадщини Митрополита Андрея під сучасну пору, слід визнати нагальність його думок та повчань для сучасної журналістики, яка потребує майже повного перезавантаження на проукраїнські позиції. Вони би мали базуватися на християнських і національних засадах.

Релігійне навчання та суспільні погляди Великого Митрополита потребують подальшого ідейно-тематичного аналізу та пропагування в ЗМІ задля пізнання широкими верствами українського суспільства неоціненності його багатого доробку у формі писемних послань і також задля актуалізації тих ідей, які ставив на порядок денний їх талановитий автор - душпастир, владика, меценат, релігійно-національний лідер свого часу.

\section{REFERENCES}

1. Баб'як А. Подвиг Митрополита Андрея Шептицького як апостольського візитатора для українців (1920-1923рр.). Тренто-Больцано, 2013.

2. Гринчишин Михаїл, Апостольський екзарх українців Франції, Швейцарії та країн Бенілюксу. Введення // Митрополит Андрей Шептицький. Пастирські послання 1899-1914 рр. в 3 т. Т.1. Львів : Видавництво «Артос», 2007. L+1014 с.

3. Там само.

4. «Лотос». 1950. Т. 1. Кн. 4; «Лотос». 1951. Т. 4. Кн. 2, 3, 4. 
5. «Світло». 2001. Ч. 7-8.

6. Дзюрах Богдан, єпископ-помічник Київської Архієпархії УГКЦ. Великий і небуденний пастир // Митрополит Андрей Шептицький. Пастирські послання 18991914 рр. в 3 т. Т. 1. Львів : Видавництво «Артос», 2007. L+1014 с.

\title{
THE EPISTLES OF METROPOLITAN ANDREY SHEPTYTSKY: THE MATIONAL-SPIRITUAL LEGACY FOR SCHOLARS AND JOURALISTS
}

\author{
Maryan Lozynskyi \\ Ivan Franko National University of Lviv \\ Gen. Chuprynky street, 49, 79044, Lviv, Ukraine \\ e-mail: mlozynskyj@lnu.edu.ua \\ https://orcid.org/0000-0002-5006-3291
}

The figure of Metropolitan Andrey Sheptytsky (1865-1944) belongs to the spiritual and national leaders of the Ukrainian people in the first half of the 20th century. The Soviet period in our history witnessed the forging of a number of negative stereotypes of this personality which even included the unjustly assigned label of a collaborator with the German occupational authorities. By now the historians have made public numerous pages describing the Metropolitan's many-sided life and service for the benefit of his people whom he unfailingly and devoutly served in the hard times of the 20th century.

Sheptytsky joined the Basilian monastic order. After a while he was nominated Bishop of Stanislaviv, Later on up until his demise he was Primate of the Episcopal see at the St. George's Cathedral of the Galician Metropolis in Lviv. He was an exceptionally educated clergyman and a spiritual father of priests and monastics as well as the entire congregation of the Greek Catholic Church. Sheptytrsky was recognized as a moral authority and leader of the Ukrainians of Galicia during the time between the two world wars and the German occupation of 19411944. His word of faith, hope and Christian principles fell on the ears of the faithful from the rostrums. Ha also authored numerous written works of different genres.

The year 2020 marks the 120th anniversary since the time when Metropolitan Andrey Sheptytsky came to the Episcopal see of the Galician Metropolitan at the St. George's Cathedral in Lviv,. The paper discusses the topics of his epistles published in four volumes due to the endeavors of scholars and historians from within the Ukrainian Greek Catholic Church. Special attention is paid to the significance of the ideas inherent to the epistles of Metropolitan Andrey for the Ukrainian society at large as well as scholars and journalists.

Key words: written legacy, epistles, form, Metropolitan Andrey Sheptytsky, church, society, journalism. 